\title{
Silymarin and Oral Health
}

\author{
Elham Ahmadian* \\ Dental and Periodontal Research Center, Tabriz University of Medical Sciences, Iran
}

Submission: July 27, 2018; Published: September 12, 2018

*Corresponding author: Elham Ahmadian, Dental and Periodontal Research Center, Tabriz University of Medical Sciences, Tabriz, Iran; Tel: +98-(41)-33372250; Email: ahmadiane@tbzmed.ac.ir

\section{Abstract}

Polyphenols are natural phytochemicals abundant in plant-derived food. Silymarin is a well-known polyphenol in milk thistle. Literature search has fetched protective role of lycopene in different disease such as cancer and liver dysfunction. Oral cancer, dental and periodontal disease are among the most important disease affecting oral health. Several studies have supported the positive role of silymarin and its constituents in these ailments mainly through antioxidant and anti-inflammatory effects. More studies will reveal the beneficial effects of this valuable natural compound in oral health. This mini review is a short view of the protective role of silymarin in the management of oral disease.

Keywords: Silymarin; Silibin; Oral health; Periodontal disease; Oral cancer

\section{Introduction}

Silymarin derived from Silybum marianum or milk thistle has been widely used as an effective herbal medicine in hepatic disorders. Global prescription of silymarin is increasing due to its safety. Different products of silymarin are approved and sold all over the world [1].

Silymarin as a polyphenolic flavonoid is extracted from the seeds of silybum marinum plant. Flavonolignans are the major components of silymarin as well as oxidized and polymeric polyphenols. Silybin is the most active constituent of silymarin claimed for the plants therapeutically effects. Tens of thousands of empirical and clinical studies have shown that the plausibility of acute and chronic silymarin toxicity is scanty, so it is a safe supplement [2,3].

Hepatoprotective activities, skin protection and cancer treatment have been documented to be the beneficial effects of silymarin in human health [4]. Also, recent knowledge has shown the protective role of silymarin in prevention and treatment of oral disease which will be discussed in this short review.

\section{Silymarin and oral mucositis}

Oral mucositis as a common side effect induced by chemotherapy or radiation during treatment of different head and neck cancer can extensively damage oral mucosa. Cytotoxic effects of chemotherapy occur via the production of free radicals and/ or several transcription factors which result in the up regulation of pro-inflammatory cytokines [5]. Also, an upward trend in the transcription of apoptotic proteins could result in severe tissue damages after chemotherapy [6]. The impact of silymarin in reduction of chemotherapy induced oral mucositis have been investigated in clinical studies. In a double-blind prospective study, silymarin (140mg) showed a 100\% pain relief and ulcer healing in oral mucositis patients. According to molecular assessments these protective effects were mediated through the antioxidant and anti-inflammatory properties of silymarin [7]. In another clinical trial, silymarin at the dosage of $420 \mathrm{mg}$ daily was commenced at the first day of radiation up to 6 weeks. Mucositis was reported to be significantly reduced according to the approved grading scale scores. Also, silymarin could delay the time for the development and progression of mucositis [8].

\section{Silymarin and dental caries}

The presence of microorganism films on the tooth surface defined as dental plaques are stimulatory factors of dental caries and periodontal diseases [9]. Daily teeth brushing, and other cleaning strategies are used to reduce or eliminate these microorganisms from oral cavity [10]. Several antibiotics such as erythromycin, ampicillin and tetracycline and other agents like phenols and fluorides are widely used in this context $[11,12]$. However, long-term usage of these compounds can lead to the several adverse effects including microorganism susceptibility and gastrointestinal problems [13,14]. Thus, implantation of natural antimicrobial gain importance. The antibacterial effects of silymarin against the growth of Staphylococcus epidermidis and Bacillus subtilis has been examined in prior studies. Silymarin can effectively inhibit the growth of oral bacteria alone or in combination with antibiotics [15]. The anti-cariogenic and antifungal effects of silibin has also been determined against oral pathogens including Enterococcus faecalis, Candida albicans, Streptococcus mutans, Staphylococcus aureus and Lactobacillus 
acidophilus. According to the result silymarin and silibin are potential candidates in prohibition of endodontics infections and dental caries [16].

Anti-inflammatory effects of silymarin has been observed in human gingival fibroblasts. Since chronic inflammation is a triggering event in induction of periodontal disease, silymarin could be proposed as a potential target in periodontitis [17].

\section{Silymarin and oral cancer}

Oral cancers consist of several squamous cell carcinoma raised form different origins in oral cavity. Oral cancer is a dilapidating disease with poor prognosis and high rate of recurrence and metastasis. Silibin has been shown to decrease the invasion of lung cancer through mediating different signaling pathways [18]. In addition, silibin has stimulatory effects in initiation of apoptosis machinery in several cancer cell lines [19]. Silibin has been reported to exert anti-metastatic effects in tongue cancer cells and prohibit tumor invasiveness [20]. Silymarin interferes within the expression of apoptosis related genes and induces inhibitory effects in the growth of oral cancer [21]. It has been reported that, silymarin prohibits the proliferation of HSC oral cancer cells in a concentration dependent way caspase dependent pathway plays a key role. Silymarin augments cleavage of caspase-8 and truncated Bid that leads in the accretion of cytochrome $c$ and ultimately programed cell death [22].

\section{Conclusion}

Silymarin and its components are widely used to treat several human diseases. It is well-known anti-oxidant, anti-inflammatory and hepato-protective effects. In addition, silymarin is safe and is marketed worldwide in different products. Evidences indicate the protective role of silymarin in prevention and treatment of oral and dental diseases as a promising component.

\section{References}

1. Saller R, Meier R, Brignoli R (2001) The use of silymarin in the treatment of liver diseases. Drugs 61(14): 2035-2063.

2. Hellerbrand C (2017) The potential of silymarin for the treatment of hepatic disorders. Clinical Phytoscience 2(1): 7.

3. Fraschini F, Demartini G, Esposti D (2002) Pharmacology of silymarin. Clinical drug investigation 22(1): 51-65.

4. Dixit N (2007) Silymarin: A review of pharmacological aspects and bioavailability enhancement approaches. Indian journal of pharmacology 39(4): 172.

5. Pico JL, Avila-Garavito A, Naccache P (1998) Mucositis: its occurrence, consequences, and treatment in the oncology setting. The oncologist 3(6): 446-451.

6. Bowen JM, Gibson RJ, Cummins AG, Keefe DM (2006) Intestinal mucositis: the role of the Bcl-2 family, p53 and caspases in chemotherapy-induced damage. Supportive Care in Cancer 14(7): 713731.
7. Altaei $\mathrm{T}$ (2011) Treatment of chemotherapy-induced oral mucositis bysilymarin. Journal of baghdad college of dentistry 23(4): 81-89.

8. Elyasi S, Hosseini S, Niazi Moghadam MR, Aledavood SA, Karimi G (2016) Effect of oral silymarin administration on prevention of radiotherapy induced mucositis: a randomized, double-blinded, placebo-controlled clinical trial. Phytotherapy Research 30(11): 1879-1885.

9. Grössner-Schreiber B, Fetter T, Hedderich J, Kocher T, Schreiber S, et al. (2006) Prevalence of dental caries and periodontal disease in patients with inflammatory bowel disease: a case-control study. Journal of clinical periodontology 33(7): 478-484.

10. White DJ, McClanahan SF, Lanzalaco AC, Cox ER, Bacca L, et al. (1996) The comparative efficacy of two commercial tartar control dentifrices in preventing calculus development and facilitating easier dental cleanings. The Journal of clinical dentistry 7(2 Spec No): 58-64.

11. Allaker RP, Douglas CI (2009) Novel anti-microbial therapies for dental plaque-related diseases. International journal of antimicrobial agents 33(1): 8-13.

12. Wara-aswapati N, Krongnawakul D, Jiraviboon D, Adulyanon S, Karimbux N, et al. (2005) The effect of a new toothpaste containing potassium nitrate and triclosan on gingival health, plaque formation and dentine hypersensitivity. Journal of clinical periodontology 32(1): 53-58.

13. Feres M, Figueiredo LC, Faveri M, Stewart B, de Vizio W (2010) The effectiveness of a preprocedural mouthrinse containing cetylpyridinium chloride in reducing bacteria in the dental office. The Journal of the American Dental Association 141(4): 415-422.

14. Pigrau C, Almirante B (2009) Oxazolidinones, glycopeptides and cyclic lipopeptides. Enferm Infecc Microbiol Clin 27 (4): 236-246.

15. Lee YS, Jang KA, Cha JD (2012) Synergistic antibacterial effect between silibinin and antibiotics in oral bacteria. J Biomed Biotechnol 2012: 618081.

16. Iyangar RM, Ezhilarasan D, Gopinath P (2017) Antimicrobial Efficacy of Silymarin and Silibinin Against Oral Microorganisms. Journal of Microbiology \& Infectious Diseases 7(3): 1-5.

17. Shahidi M, Vaziri F, Haerian A, Farzanegan A, Jafari S, et al. (2017) Proliferative and Anti-Inflammatory Effects of Resveratrol and Silymarin on Human Gingival Fibroblasts: A View to the Future. Journal of Dentistry (Tehran) 14(4): 203-211.

18. Chu SC, Chiou HL, Chen PN, Yang SF, Hsieh YS (2004) Silibinin inhibits the invasion of human lung cancer cells via decreased productions of urokinase-plasminogen activator and matrix metalloproteinase-2. Mol Carcinog 40(3): 143-149.

19. Mallikarjuna G, Dhanalakshmi S, Singh RP, Agarwal C, Agarwal R (2004) Silibinin protects against photocarcinogenesis via modulation of cell cycle regulators, mitogen-activated protein kinases, and Akt signaling. Cancer Res 64(17): 6349-6356.

20. Chen PN, Hsieh YS, Chiang CL, Chiou HL, Yang SF, et al. (2006) Silibinin inhibits invasion of oral cancer cells by suppressing the MAPK pathway. Journal of dental research 85(3): 220-225.

21. Su CH, Chen LJ, Liao JF, Cheng JT (2013) Increase of phosphatase and tensin homolog by silymarin to inhibit human pharynx squamous cancer. J Med Food 16(9): 778-784.

22. Won DH, Kim LH, Jang B, Yang IH, Kwon HJ, et al. (2018) In vitro and in vivo anti-cancer activity of silymarin on oral cancer. Tumor Biology 40(5): 1010428318776170. 

(CC) Commons Attribution 4.0 License

DOI: 10.19080/ADOH.2018.09.555772
Your next submission with Juniper Publishers will reach you the below assets

- Quality Editorial service

- Swift Peer Review

- Reprints availability

- E-prints Service

- Manuscript Podcast for convenient understanding

- Global attainment for your research

- Manuscript accessibility in different formats

( Pdf, E-pub, Full Text, Audio)

- Unceasing customer service

Track the below URL for one-step submission https://juniperpublishers.com/online-submission.php 